\title{
Delayed Precursor Cell Markers Expression in Hippocampus following Cold-Induced Cortical Injury in Mice
}

\author{
TAKEHIRO NAKAMURA, ${ }^{1,2}$ OSAMU MIYAMOTO,${ }^{3}$ ROLAND N. AUER, ${ }^{4}$ SEIGO NAGAO, ${ }^{2}$ \\ and TOSHIFUMI ITANO ${ }^{3}$
}

\begin{abstract}
The purpose of this study was to examine the possibility of neuronal remodeling and repair after cold-induced brain injury using immunoassay of nestin and 3CB2 (potential precursor cell markers). Male ddN strain mice were subjected to cold-induced cortical injury. Animals were divided into the following six groups: (1) 1 day after injury, (2) 1 week after injury, (3) 2 weeks after injury, (4) 1 month after injury, (5) sham controls, and (6) normal controls. Western blot analysis ( $n=3$ in each group) and histological examination ( $n=5$ in each group) were performed. At 1 day and 1 week after injury, TUNEL-positive cells were observed, while immunoreactivity of nestin and $3 C B 2$ was absent. At 1 month after injury, expression of both nestin and 3CB2 was observed in the ipsilateral hippocampus. Nestin was expressed in GFAP- or 3CB2-positive astrocytes at 1 month after injury, and nestin expression with TUC-4 (immature neuron marker) was present in the hippocampal cell layer. The findings demonstrate delayed nestin expression in both glia and neuronlike cells after brain injury. The present study suggests that the delayed nestin expression in glia and neuron-like cells might be part of the adaptation to injury.
\end{abstract}

Key words: 3 CB2; cold-induced brain injury; mice; migration; nestin; remodeling

\section{INTRODUCTION}

$\mathbf{P}$ athological events in traumatic brain injury may be divided into primary and secondary brain injury (Nakamura et al., 1999a; Sahuquillo et al., 1993). Primary brain injury occurs at the time of the insult, whereas secondary injury follows during the recovery period. Furthermore, reparative processes may occur following damage to the tissue. Eventually, the reaction results in the formation of gliotic scar (Malhotra et al., 1990). However, there are few data on long-term reparative processes after traumatic brain injury.

Nestin is an intermediate filament protein, transiently expressed early in embryogenesis in neuroepithelial cells, radial glia, germinal matrix cells, and vascular cells. It was originally found as the antigen recognized by a mouse monoclonal antibody known as RAT-401 (Hockfield and McKay, 1985). It is only present in endothelial

\footnotetext{
${ }^{1}$ Department of Neurosurgery, University of Michigan, Ann Arbor, Michigan.

Departments of ${ }^{2}$ Neurological Surgery and ${ }^{3}$ Neurobiology, Kagawa University Faculty of Medicine, Kagawa, Japan.

${ }^{4}$ Department of Pathology and Laboratory Medicine and Clinical Neurosciences, University of Calgary, Calgary, Alberta, Canada.
} 
and select subventricular cells in adults, but it is upregulated in astrocytes and neurons after experimental cerebral ischemia (Li and Chopp, 1999), and its presence may reflect a more multipotent phenotype. Nestin has been reported in reactive astrocytes (Holmin et al., 1997; Kaya et al., 1999) and neurons (Kuroda et al., 2002) following brain injury. Nestin expression might be due to progenitor cells that have migrated from the subventricular zone (Holmin et al., 1997; Kaya et al., 1999) under induction by some factors released from injury site (Kuroda et al., 2002). These studies suggest that nestin expression may contribute to remodeling after injury.

Radial glia proliferate actively during neurogenesis, inducing migration of neurons (Misson et al., 1988). After neuronal migration is finished, the radial glia either disappear or differentiate into astrocytes (Chanas-Sacre et al., 2000; Misson et al., 1991). However, recent studies have reported that radial glia not only serve as a guide for neurons, but also have properties of neural progenitor cells (Campbell and Gotz, 2002; Parnavelas and Nadarajah, 2001). Radial glia can be detected by immunoassay using 3CB2 (Prada et al., 1995). There are few reports on the presence of radial glia after traumatic brain injury. The present study investigates the appearance of nestin and $3 \mathrm{CB} 2$ immunoreactivity, as potential precursor cell markers, in a cold-induced brain injury model.

\section{MATERIALS AND METHODS}

\section{Animals and Cold-Induced Cortical Injury}

ddN strain mice (25-30 g body weight), inbred in our laboratory (Nakamura et al., 1999a; Miyamoto et al., 2000), were used for this study. Animal protocols were approved by the Kagawa University Animal Committee. Forty-eight male mice were given free access to food and water prior to experiment. Animals were anesthetized with sodium pentobarbital (30 mg/kg i.p.), with supplemental doses given as necessary, and then placed in a stereotactic frame (Narishige Instruments, Japan). Rectal temperature was maintained at $37^{\circ} \mathrm{C}$ using a feedbackcontrolled heating pad (CMA, Stockholm, Sweden) during the operation. The scalp was incised in the midline and the skull exposed. A cold-induced brain injury was generated by application of a metal probe $(3 \mathrm{~mm}$ in diameter) cooled with liquid nitrogen to the exposed right parietal bone for $20 \mathrm{sec}$ (Fig. 1A). The animals were divided into following six experimental groups: (1) 1 day after injury, (2) 1 week after injury, (3) 2 weeks after injury, (4) 1 month after injury, (5) sham control, and (6) normal control.

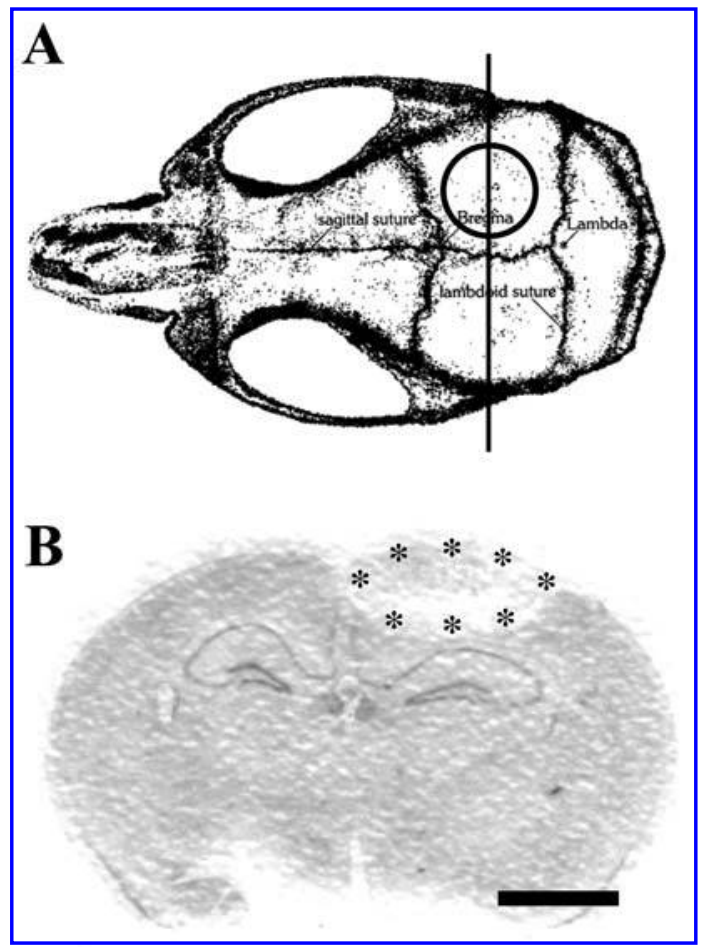

FIG. 1. (A) Location of cold-induced injury on mouse skull. Circle shows the lesion area for the cold-induced brain injury. The vertical line shows the position for making coronal slices. (B) Hemotoxylin-stained coronal brain slice at 1 day after injury. Lesions were observed in right (ipsilateral) cortex at this time point. *Cortical lesion location. Bar $=2.0 \mathrm{~mm}$.

\section{Western Blot Analysis}

Animals were anesthetized with sodium pentobarbital $(50 \mathrm{mg} / \mathrm{kg}$ i.p.) before undergoing intracardiac perfusion with $0.1 \mathrm{M}$ phosphate-buffered saline (PBS, $\mathrm{pH}$ 7.4). The brains were removed, and the ipsilateral and contralateral hippocampi separated. Western blot analysis was performed as previously described (Bagum et al., 2001). Briefly, $25 \mu \mathrm{g}$ of protein from each sample was separated by sodium dodecyl sulfate polyacrymide gel electrophoresis and transferred to a Hybond-C pure nitrocellulose membrane (Amersham, Piscataway, NJ). The membranes were blocked in Carnation nonfat milk. Membranes were probed with a 1:1000 dilution of the primary antibodies, monoclonal mouse anti-nestin or anti-3CB2 (Developmental Studies Hybridoma Bank, University of Iowa) followed by a 1:1500 dilution of the secondary antibody (peroxidase-conjugated goat antimouse, BioRad Laboratories, Hercules, CA). The antigen-antibody complexes were visualized with a chemi- 
luminescence system (Amersham) and exposed to film. The relative densities of bands were analyzed with NIH Image.

\section{Histological Examination}

For histological examination, animals were sacrificed under deep anesthesia using sodium pentobarbital (50 $\mathrm{mg} / \mathrm{kg}$ i.p.). The brains were transcardially perfused with 4\% phosphate-buffered paraformaldehyde after flushing with $0.1 \mathrm{M}$ PBS. The brains were removed and placed in fixative overnight. Adjacent paraffin sections (coronal sections; $10 \mu \mathrm{m}$ thick) were made. Sections of the CA1 area (including the dorsal hippocampal area) around 2.0 $\mathrm{mm}$ posterior to bregma were obtained (Fig. 1) (Franklin and Paxinos, 1997).

For evaluation of neorodegeneration following coldinduced brain injury, the terminal deoxynucleotidyl transferase-mediated dUTP nick end-labeling technique was performed on adjacent brain sections to detect DNA double-strand breaks according to the method described by Xu et al. (1998). ApopTag Peroxidase Kits (Serologicals, Temecula, CA) were used in this study. In this method, $0.05 \mathrm{M}$ PBS was used as solution for dilution and washing. The sections were permeabilized with $1 \%$ Triton $\mathrm{X}$ 100 for $30 \mathrm{~min}$ and endogenous peroxidases quenched with $2 \% \mathrm{H}_{2} \mathrm{O}_{2}$ for $20 \mathrm{~min}$. After washing with PBS, the sections were incubated in a moist chamber at $37^{\circ} \mathrm{C}$ for 60 min with TdT enzyme. After anti-digoxingenin peroxidase had been applied to the sections for $30 \mathrm{~min}$ at room temperature, peroxidase was detected with DAB. The labeling target of this method was the new $3^{\prime}-\mathrm{OH}$ DNA ends generated by DNA fragmentation. The omission of the terminal deoxynucleotidyl transferase was used as the negative control. Sections were counterstained with hemotoxylin.

Immunohistochemistry was performed using the avidin-biotin complex method (Nakamura et al., 1999b; Shibuya et al., 2002). The sections were stained by nestin, $3 \mathrm{CB} 2$, and glial fibrillary acidic protein (GFAP) immunohistochemistry. After blocking of nonspecific reactions with 5\% skim milk and washing in $0.01 \mathrm{M}$ PBS, a monoclonal mouse anti-nestin (1:100), a monoclonal mouse anti-3CB2 anti-body (1:100), or a polyclonal rabbit anti-GFAP antibody (1:200) (DAKO, Glostrup, Denmark) were applied to sections overnight at $4^{\circ} \mathrm{C}$. The sections were incubated with second biotinylated antibodies for $60 \mathrm{~min}$ and an avidin-biotin-peroxidase complex for 60 min (ABC Kit; Vector, Burlingame, CA). The final reaction for peroxidase was carried out with $0.05 \%$ diaminobenzidine and $0.005 \% \mathrm{H}_{2} \mathrm{O}_{2}$. Counterstaining was performed with hemotoxylin. The number of nestin-positive cells were counted in the ipsilateral hippocampal
CA1 pyramidal band by an observer blind to the treatment conditions ( $n=5$ in each group).

Double labeling was performed as previously described (Shibuya et al., 2003). Briefly, sections were incubated overnight at $4^{\circ} \mathrm{C}$ with monoclonal mouse anti-nestin antibody and polyclonal rabbit anti-GFAP antibody diluted, respectively, to $1: 100$ and $1: 200$ in $1 \%$ skim milk solution in $0.01 \mathrm{M}$ PBS. After washing with $0.01 \mathrm{M}$ PBS, the reactions for nestin and GFAP were visualized after incubation for $2 \mathrm{~h}$ at room temperature with anti-mouse immunoglobulin (IgG) conjugated with fluorescein isothiocyanate (FITC) (Vector) and anti-rabbit IgG conjugated with Texas red avidin D (Vector). The secondary antibodies were both diluted 1:40 in 1\% skim milk solution in $0.01 \mathrm{M}$ PBS. Finally, the sections were rinsed in $0.01 \mathrm{M}$ PBS and visualized using a confocal laser-scanning microscope (LSM-GB200; OLYMPUS, Tokyo, Japan). Other sections were used for double la-

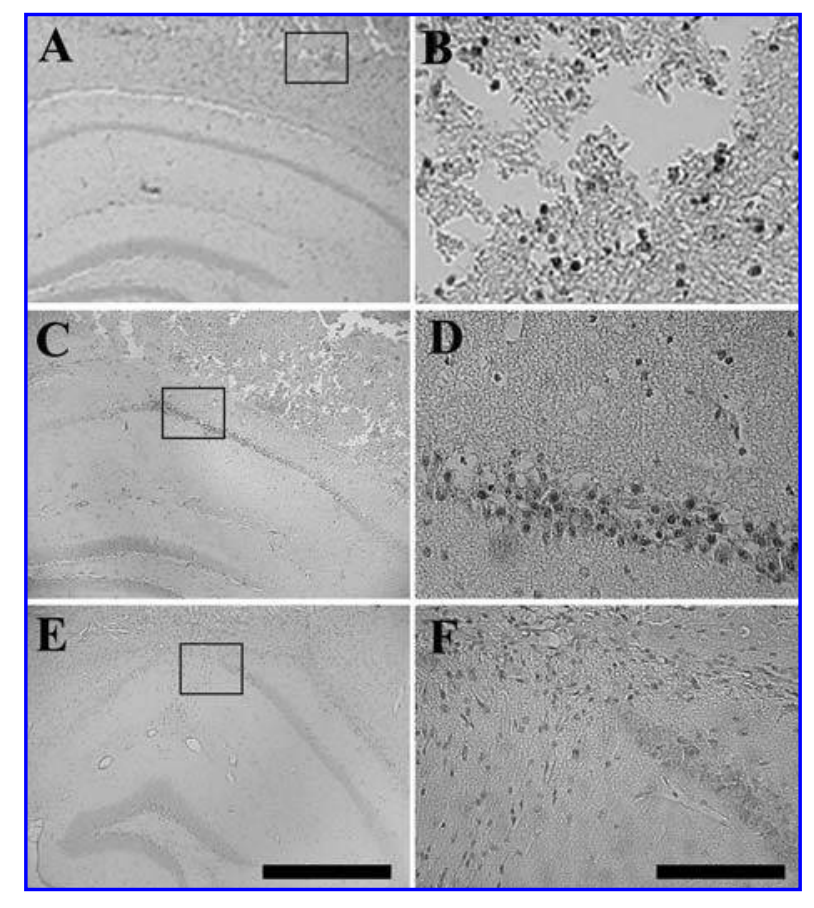

FIG. 2. Photomicrographs of the hippocampus with a method allowing in situ labeling of DNA fragmentation in tissue sections (TUNEL staining). (A) Low magnification in the ipsilateral hippocampus at 1 day after injury, no staining is yet visible in CA1. (B) High magnification showing some positive cells in the ipsilateral cortex. (C,D) Low and high magnification of the ipsilateral hippocampus at 1 week after injury, showing a stretch of TUNEL-positive neurons in the CA1 pyramidal cell band. (E,F) Low and high magnification of the ipsilateral hippocampus at 1 month after injury showing no staining in the remaining cells. $\mathrm{B}, \mathrm{D}$, and $\mathrm{F}$ show enlargement of the boxed areas from A, C, and E. Bar $=500 \mu \mathrm{m}$ (A,C,E), $50 \mu \mathrm{m}(\mathrm{B}, \mathrm{D}, \mathrm{F})$. 
beling of nestin and 3CB2. Monoclonal mouse anti-3CB2 antibody was diluted to $1: 100$, and anti-mouse IgG conjugated with Texas red avidin D (1:40) (Vector) was used as the second antibody. Additionally, some sections were used for double labeling of nestin and immature neuronal marker TUC-4 (Cameron and McKay, 2001). Polyoclonal rabbit anti-TUC-4 antibody was diluted to 1:100, and anti-rabbit IgG conjugated with Texas red avidin D (1:40) (Vector) was used as the second antibody.

\section{Statistical Analysis}

All data in this study are presented as mean \pm SD. Data from Western blot analysis was analyzed with Student's $t$-test. Cell counting data were used by analysis of variance (ANOVA), followed by Scheffe's post hoc test.

\section{RESULTS}

\section{Cold-Induced Cortical Injury}

The present study employed a cold-induced brain injury model. In this model, the visible lesion is limited to

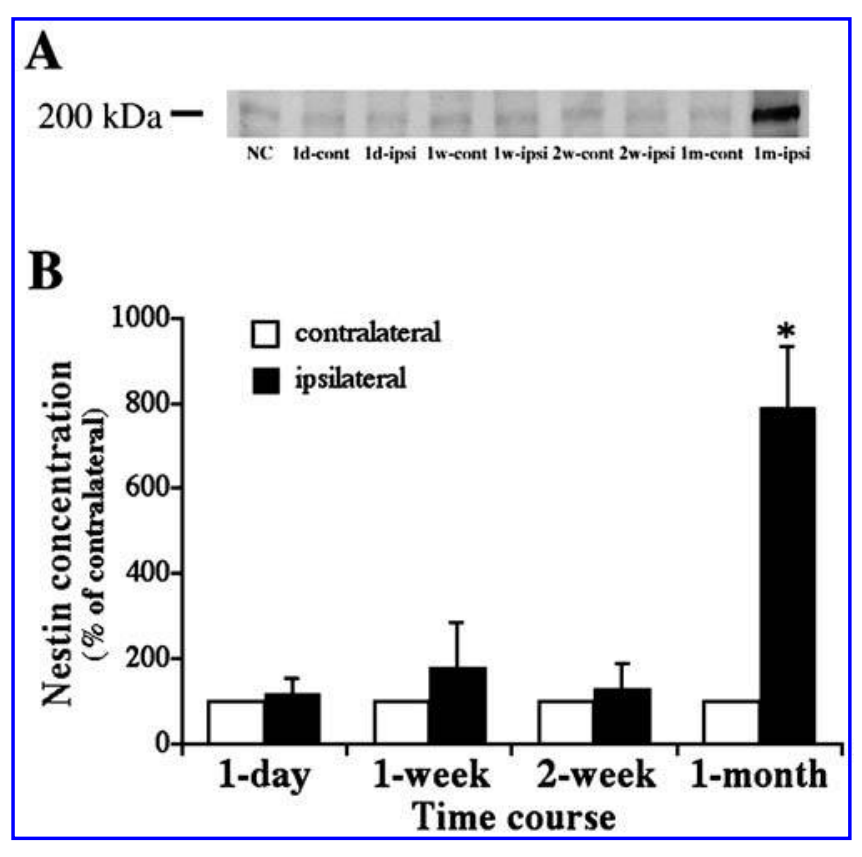

FIG. 3. (A) Western blot analysis showing the effect of brain injury on nestin concentration in the hippocampus. Bands are from normal control (NC) and the contralateral and ipsilateral hippocampus either 1 day (1d-cont and 1d-ipsi), 1 week (1wcont and $1 \mathrm{w}$-ipsi), 2 weeks ( $2 \mathrm{w}$-cont and $2 \mathrm{w}$-ipsi), or 1 month (1m-cont and $1 \mathrm{~m}$-ipsi) after injury. Equal amounts of protein (25 $\mu \mathrm{g}$ ) were used. (B) The graph shows Western blot analysis of time course of nestin expression in the contralateral and ipsilateral hippocampus 1 day, 1 week, 2 weeks, and 1 month after injury ( $n=3$ in each group). Values are means \pm SD. $* p<0.01$ compared with the contralateral hippocampus.

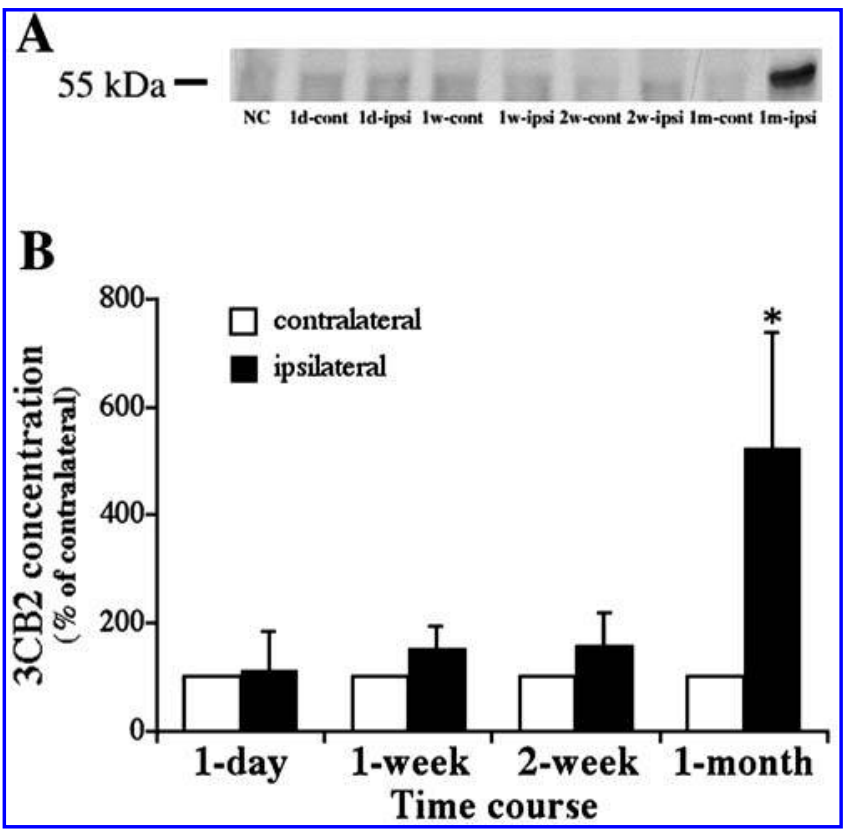

FIG. 4. (A) Western blot analysis showing the effect of brain injury on the $3 \mathrm{CB} 2$ concentration in the hippocampus. Bands are from normal control (NC) and the contralateral and ipsilateral hippocampus either 1 day (1d-cont and 1d-ipsi), 1 week (1w-cont and $1 \mathrm{w}$-ipsi), 2 weeks ( $2 \mathrm{w}$-cont and $2 \mathrm{w}$-ipsi), or 1 month (1m-cont and 1m-ipsi) after injury. Equal amounts of protein $(25 \mu \mathrm{g})$ were used. (B) The graph shows Western blot analysis of time course of $3 \mathrm{CB} 2$ expression in the contralateral and ipsilateral hippocampus 1 day, 1 week, 2 weeks, and 1 month after injury ( $n=3$ in each group). Values are means \pm SD. ${ }^{*} p<0.05$ compared with the contralateral hippocampus.

the ipsilateral cortex in the acute phase. Figure 1B shows a hemotoxylin-stained coronal brain section 1 day after injury demonstrating the right (ipsilateral) cortical lesion at this time point.

\section{TUNEL Staining}

We observed staining of some clustered cells in the core area of the cold-induced lesion at 1 day after injury (Fig. 2A,B). There was expansion of lesion stained by TUNEL positive cells to include positive CA1 pyramidal cell in the ipsilateral hippocampus at 1 week after injury (Fig. 2C,D). The TUNEL-positive cells were already resolved at 1 month after injury. Migration changes were seen in the ipsilateral hippocampal stratum radiatum area at 1 month after injury by counter-staining (Fig. 2E,F).

\section{Western Blot Analysis}

By Western blot analysis, there was no increase in nestin protein levels in the ipsilateral hippocampus from 1 day to 2 weeks after injury (Fig. 3). However, there 


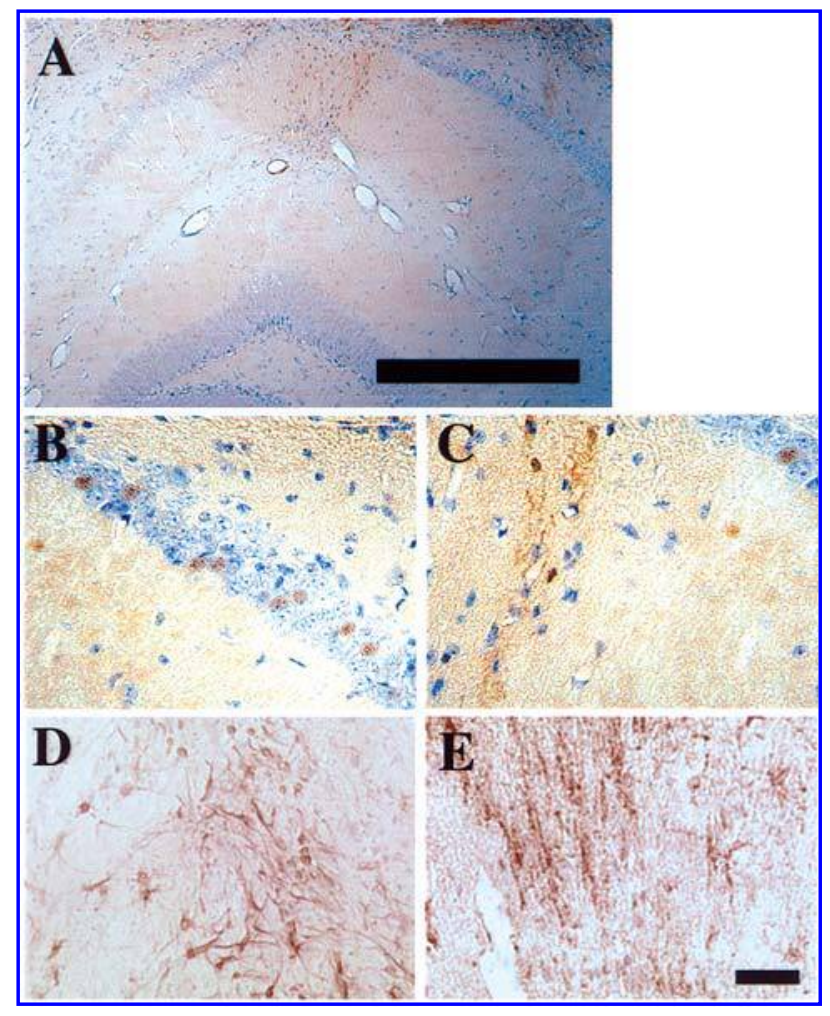

FIG. 5. Photomicrographs of the ipsilateral hippocampus with immunohistochemistry for nestin (A-C), 3CB2 (D), and GFAP (E) in the 1-month-after-injury group. Low magnification in the ipsilateral hippocampus (A). Micrographs at high magnification are from the $\mathrm{CA} 1$ area $(\mathrm{B})$ or the striatum radiatum area $(\mathrm{C}-\mathrm{E})$. Nestin staining is apparent in glia in the hippocampus and also surviving CA1 pyramidal neurons. 3CB2 and GFAP positive glia cells are seen in the hippocampal striatum radiatum area. $\mathrm{Bar}=500 \mu \mathrm{m}(\mathrm{A}), 20 \mu \mathrm{m}(\mathrm{B}-\mathrm{E})$.

FIG. 7. Immunofluorescent double labeling for nestin and GFAP (A-I), nestin and 3CB2 (J-L) or nestin and TUC-4 (M-O) in the ipsilateral hippocampus (A-F, J-O) or subventricular zone (G-I) 1 month after cold-induced cortical injury. $\mathrm{A}-\mathrm{C}$ and $\mathrm{M}-\mathrm{O}$ are from the hippocampal striatum pyramidale (CA1) region, D-F are from the hippocampal striatum radiatum, and $\mathrm{G}-\mathrm{I}$ are from the subventricular zone. A,D,G,J,M) show FITClabeled nestin, B,E,H show Texas red-labeled GFAP, $\mathrm{K}$ shows Texas red-labeled 3CB2, N shows Texas red-labeled TUC-4, C,F,I shows double labeling of nestin and GFAP, L shows double labeling of nestin and $3 \mathrm{CB} 2$, and $\mathrm{O}$ shows double labeling of nestin and TUC-4. Photomicrographs show that nestin-immunoreactive cells are present in the hippocampal stratum pyramidale area (A), along with GFAP-positive cells (B). Whereas some cells are immunopositive for both markers (orange in $\mathrm{C}$ ), some cells with a neuron-like morphology are only positive for nestin (arrow, A,C). In the stiatum radiatum, nestin (D) and GFAP (E) were co-expressed (F). There were also co-expression of nestin $(\mathrm{G})$ and GFAP $(\mathrm{H})$ in subventricular zone (I). In the striatum radiatum, nestin $(\mathrm{J})$ and $3 \mathrm{CB} 2(\mathrm{~K})$ were also co-expressed (L). In the striatum pyramidale area, nestin (M) and TUC-4 (N) were coexpressed (O). Bar $=20 \mu \mathrm{m}$.

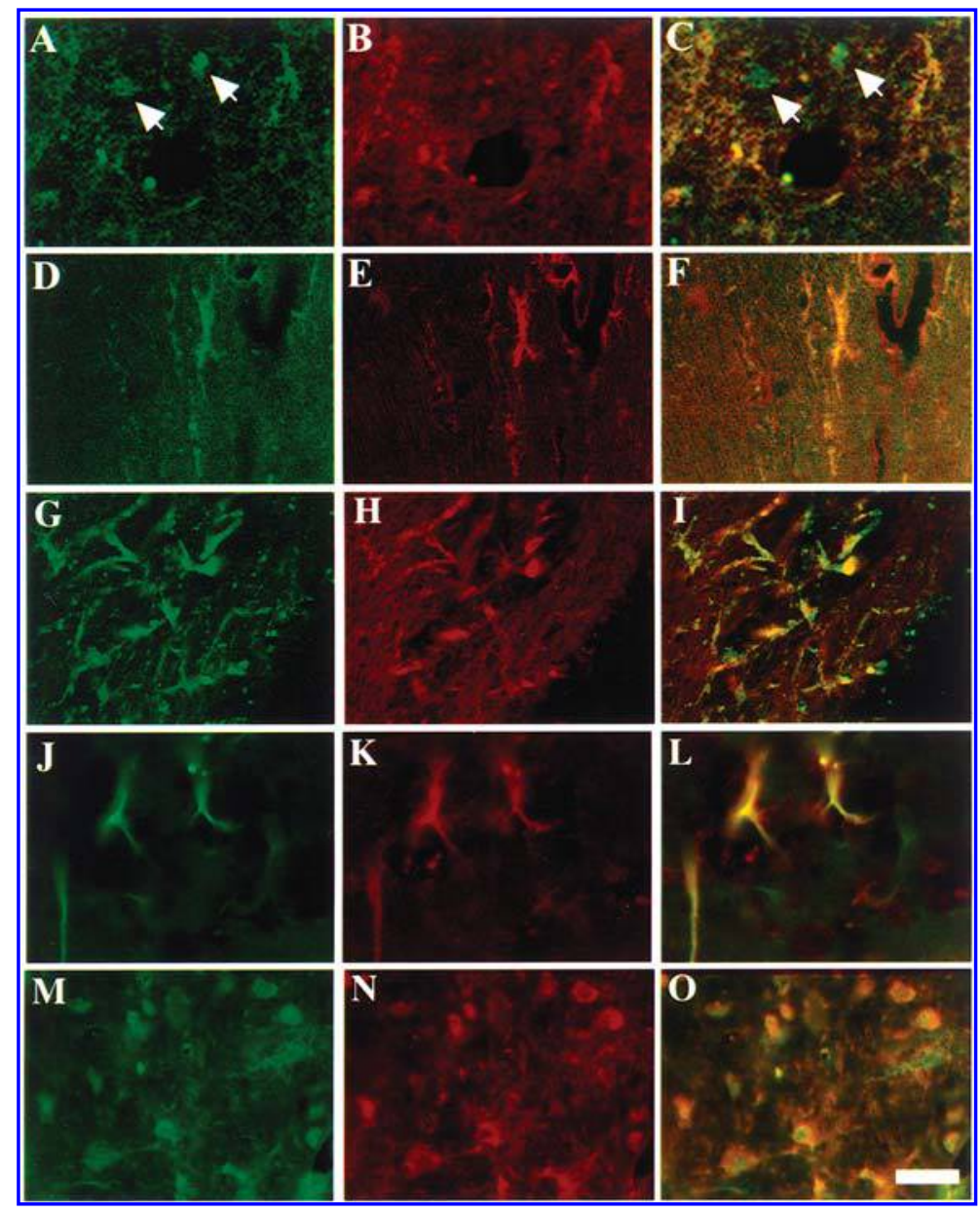


was strong expression 1 month after injury $(791 \pm 144 \%$ of contralateral, $p<0.01$ ).

Protein levels of $3 \mathrm{CB} 2$ showed a similar temporal profile. There was no increase at 1 day, 1 and 2 weeks, but a robust increase in the ipsilateral hippocampus at 1 month after injury (524 $\pm 215 \%$ of contralateral, $p<0.05$; Fig. 4).

\section{Immunohistochemistry}

Nestin and 3CB2 were absent from astrocytes and neurons in sham and normal control groups. After induction of brain injury, nestin and 3CB2 immunoreactivity was also absent at 1 day, and 1 and 2 weeks after injury (data not shown), similar to the Western blot findings. Nestin expression was observed in the ipsilateral hippocampal stratum pyramidale and radiatum area at 1 month after injury (Fig. 5A-C). 3CB2 was also expressed in astrocytes in the ipsilateral hippocampus at 1 month (Fig. 5D). Representative photomicrographs of GFAP immunohistochemical staining in the hippocampus at 1 month after injury are shown in Figure. 5E.

Interestingly, nestin-positive neuron-like cells were observed in the ipsilateral hippocampal CA1 cell layer at 1 month after injury (Fig. 5B). However, there was no immunoreactivity for $3 \mathrm{CB} 2$ in the ipsilateral $\mathrm{CA} 1$ cell band. The number of nestin positive cells in CA1 band was significantly increased at 1 month after injury $(18.7 \pm 12.7$ cells $/ \mathrm{mm}, p<0.05)$ compared with normal controls, and 1 day and 1 week injury groups (Fig. 6A). Nestin positive neuron-like cells could be observed in each animal of 1 month after injury (range, 5.3-32.8 cells $/ \mathrm{mm})$.

Moreover, nestin-positive glia cells were seen in the ipsilateral subventricular zone. There was significant increase at 1 month after injury $(50.8 \pm 18.9$ cells $/ \mathrm{mm}, p<$ 0.01 , Fig. 6B). Nestin-positive glia cells could be observed in each animal 1 month after injury (range, 21.272.1 cells/mm).

\section{Immunofluorescent Double Labeling}

Nestin appeared to be localized to both glia cells and neurons in the ipsilateral hippocampus at 1 month after injury, as assessed using double labeling for nestin and GFAP (Fig. 7A-I), nestin and 3CB2 (Fig. 7J-L), or nestin and TUC-4 (Fig. 7M-O). Immunoreactivity for both nestin and GFAP was present in the ipsilateral hippocampus CA1 pyramidal cell layer (Fig. 7A-C) and in the hippocampal striatum radiatum (Fig. 7D-F). Interestingly, nestin-positive neuron-like cells that were not GFAP immunoreactive were observed in the ipsilateral hippocampus CA1 cell layer (Fig. 7A-C, arrows). The nestin-positive neuron-like cells were co-expressed with TUC-4 (Fig. 7M-O).

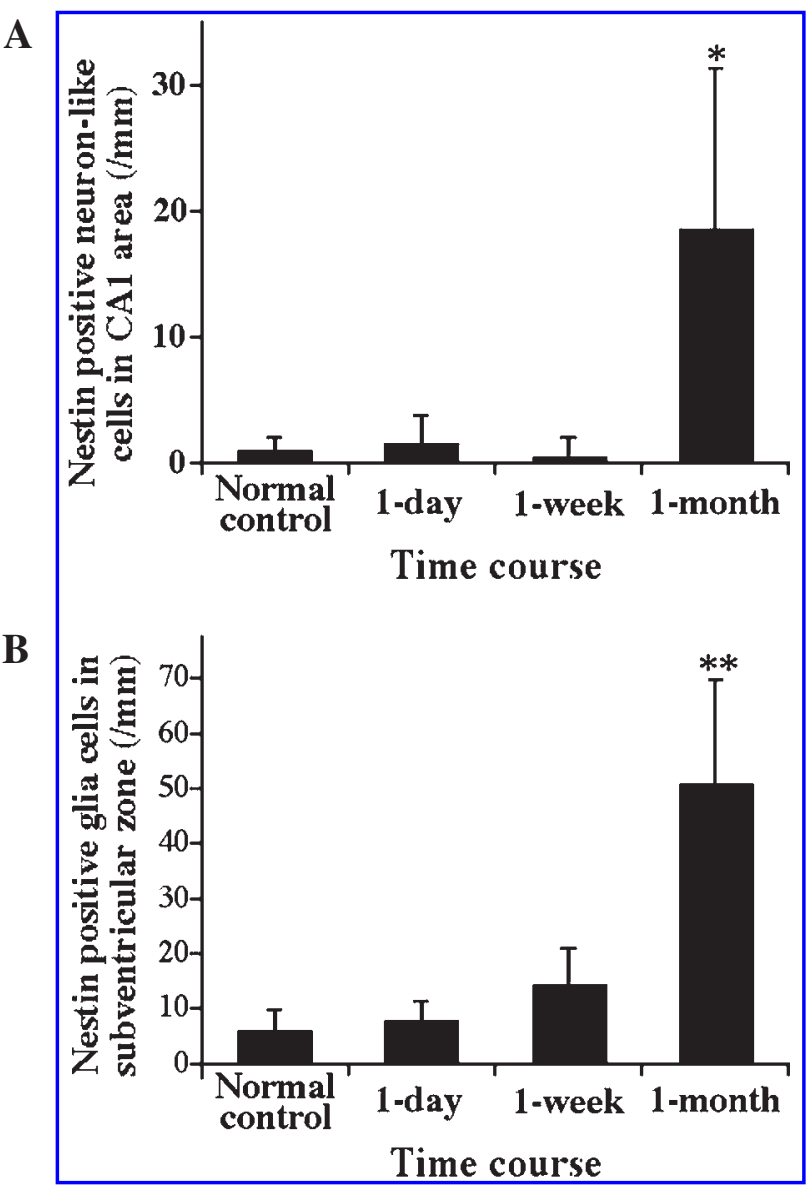

FIG. 6. Counting of nestin-positive neuron-like cells in the hippocampal CA1 pyramidal cell layer (A) and for nestin-positive glia cells in the subventricular zone $(\mathbf{B}) . n=5$ in each group. $* p<0.05$ and $* * p<0.01$ compared with the other groups by ANOVA.

Co-expression of nestin and GFAP were seen in glia cells in the ipsilateral subventricular zone (Fig. 7G-I). In the striatum radiatum, nestin and $3 \mathrm{CB} 2$ were also co-expressed (Fig. 7J-L).

\section{DISCUSSION}

\section{Degeneration and Remodeling after Brain Injury}

Neuronal cell death after traumatic brain injury can be divided into two categories: acute cell death due to primary injury and delayed cell death as a result of secondary injury. In the present study, there was expansion of lesion stained by TUNEL-positive cells to include positive CA1 pyramidal cell in the hippocampus at 1 week after injury; that is, delayed cell death appeared to continue for at least 1 week after cold-induced brain injury. 


\section{PRECURSOR CELL MARKERS EXPRESSION AFTER INJURY}

It is important to note that TUNEL staining is not specific for apoptosis (Perry et al., 2001), as TUNEL-positive cells can be present during apoptosis, necrosis, and autolysis (Grasl et al., 1995).

The possibility of neurogenesis exists following acute and delayed cell death in traumatic brain injury. Several studies have indicated some remodeling changes following brain injury (Dash et al., 2001; Suzuki and Choi, 1991; Yang et al., 1997). Suzuki and Choi (1999) demonstrated repair and reconstruction of the cortical plate following brain injury to the neonatal rat. Dash et al. (2001) showed that brain injury increased the production of new granule neurons in dentate gyrus. Yang et al. (1997) demonstrated that an increase in reactive astrocytes at the immediate site of cerebral cortical injury in rat was related to tissue remodeling. However, the precise mechanisms involved in remodeling following brain injury is not fully understood. In the present study, dynamic histological changes were seen by immunohistochemical examination.

\section{Precursor Cell Markers Expression in Hippocampus after Cortical Injury}

The adult brain tissue consists of neurons and glia that are generated by precursor cells from the embryonic ventricular zone. During postnatal development of the central nervous system, intermediate filament proteins are subjected to a remodeling process (Wei et al., 2002). Nestin is a distinct neurofilament protein expressed transiently in immediate precursors to neurons and glia (Clarke et al., 1994), and nestin expression is regarded as correlating with progenitor cells in the central nervous system (Dahlstrand et al., 1995). The presence of nestin has been reported in the hippocampus and selected subventricular zones in normal adult rat (Dahlstrand et al., 1995; Doetsch et al., 1999; Monma et al., 2000). Nestin mRNA expression is also detected in limited regions such as the hippocampus and selected subventricular zones in normal adult mammalian brain (Dahlstrand et al., 1995).

Previous studies on focal cerebral ischemia (Duggal et al., 1997) and traumatic brain injury (Kaya et al., 1999) in rat have also revealed expression of nestin. These findings suggested an embryonic reversion of the mature cytoskeleton in response to and recovery after cerebral injury (Duggal et al., 1997; Kaya et al., 1999). Brook et al. (1999) demonstrated that traumatic injury to the dentate gyrus is followed by the rapid but transient expression of nestin in astrocytes located in the stratum lucidum of field CA3. In the present study, nestin expression in GFAP was observed in the stratum radiatum, perivascular area and subventricular zone one month after injury. Astrocytes play a role in maintain- ing physiological and metabolic homeostasis in the brain (Barres et al., 1992; Duggal et al., 1997), functions that may play a vital in the response to brain injury. Transformation of normal resting astrocytes to reactive astrocytes occurs in areas with ischemic damage (Duggal et al., 1997; Takamiya et al., 1988). Laying down of a glial scar is a repair mechanism performed by reactive astrocytes. Some modifications that occur in astrocytic intermediate filament composition may be associated with the reactive changes (Duggal et al., 1997). Nestin-containing glial cells may play an important role in remodeling and development (Wei et al., 2002). Nestin is detectable in neuroepitherial cells and glial fibers during the stage of migration (Doyle et al., 2001; Alves et al., 2002). The activation of astrocytes following insult might underlie the ectopic migration of subventricular zone neuroblasts toward damaged brain regions (Parent et al., 2002). Moreover, glial-derived factors can increase the migration rate of neuroblasts in explant cultures of the neonatal rat subventricular zone and olfactory bulb pathway (Manson et al., 2001). In the present study, nestin and $3 \mathrm{CB} 2$ positive astrocytes were also seen in the perivascular area and subventricular zone. Especially, there were significant increases in nestin expression in GFAP-positive cells in the ipsilateral subventricular zone one month after injury. These results suggests that the activation of nestin-positive astrocytes following injury might underlie the ectopic migration of subventricular zone neuroblasts toward damaged hippocampal area one month after injury.

Nestin may play an important role in migration and restructuring of the glial cytoskeleton and may also facilitate the formation of new synaptic connections in neurons (Duggal et al., 1997). In general, glia are generated after neurons during development. Radial glia are, however, an exception to this rule being generated before neurogenesis and neuronal migration (Rakic, 1972). Radial glia are mitotically active throughout neurogenesis (Misson et al., 1988), and disappear or become astrocytes when neuronal migration is complete (Chanas-Scare et al., 2000; Misson et al., 1991). Noctor et al. (2001) showed that neurons migrate along clonally related radial glia, and that proliferative radial glia generate neurons. In the present study, the appearance of $3 \mathrm{CB} 2$ positive radial glial cells had a similar time course to that found for nestin-positive cells. This is the first report of $3 \mathrm{CB} 2$ expression following brain injury in an in vivo model. Moreover, nestin immunoreactive cells in the hippocampal CA1 cell layer were GFAP-negative at one month after injury and they were neuron-like in appearance. These cells were co-expressed with immature neuron marker TUC-4. Whether these cells will be mature neurons requires further study. The present and others 


\section{NAKAMURA ET AL.}

studies suggest that nestin might play an important role in neuronal remodeling.

Progress in the regenerative treatment using neurotrophic factors (Galvin and Oorschot, 2003) and neural stem cells (Riess et al., 2002) has been remarkable. Treatment strategies for traumatic brain injury have been directed at attenuating secondary or delayed injury. In the present study, the authors present data showing that although experimental brain injury causes neuronal death there is the possibility of remodeling. As damaged brain tissue has the potential for neurogenesis, it is important to further explore this treatment for traumatic brain injury.

\section{ACKNOWLEDGMENTS}

This study was supported by a Grant-in-Aid for Scientific Research from the Japanese Society for the Promotion of Science. We thank Drs. Tetsuro Negi, Shinichi Yamagami, Kazunori Sumitani, and Shiro Yamashita (Kagawa University Faculty of Medicine) for excellent technical assistance. We also thank Prof. Richard F. Keep (Department of Neurosurgery and Physiology, University of Michigan) for providing useful suggestions.

\section{REFERENCES}

ALVESl, J.A., BARONE, P., ENGELENDER, S., FROES, M.M., and MENEZES, J.R. (2002). Initial stages of radial glia astrocytic transformation in the early postnatal anterior subventricular zone. J. Neurobiol. 52, 251-265.

BAGUM, M.A., MIYAMOTO, O., TOYOSHIMA, T., MASADA, T., NAGAHATA, S., and ITANO, T. (2001). The contribution of low-affinity NGF receptor (p75NGFR) to delayed neuronal death after ischemia in the gerbil hippocampus. Acta Med. Okayama 55, 19-24.

BARRES, B.A. (1992). New roles for glia. J. Neurosci. 11, 3685-3694.

BROOK, G.A., PEREZ-BOUZA, A., NOTH, J., and NACIMIENTO, W. (1999). Astrocytes re-express nestin in deafferented target territories of the adult rat hippocampus. Neuroreport 10, 1007-1011.

CAMERON, H.A., and McKAY, R.D. (2001). Adult neurogenesis produces a large pool of new granule cells in the dentate gyrus. J. Comp. Neurol. 435, 406-417.

CAMPBELL, K., and GOTZ, M. (2002). Radial glia: multipurpose cells for vertebrate brain development. Trends Neurosci. 25, 235-238.

CHANAS-SACRE, G., ROGISTER, B., MOONEN, G., and LEPRINCE, P. (2000). Radial glia phenotype: origin, regulation, and transdifferentation. J. Neurosci. Res. 61, 357-363.
CLARKE, S.R,, SHETTY, A.K., BRADLEY, J.L., and TURNER, D.A. (1994). Reactive astrocytes express the embryonic intermediate neurofilament nestin. Neuroreport $\mathbf{5}$, 1885-1888.

DAHLSTRAND, J., LARDELLI, M., and LENDAHL, U. (1995). Nestin mRNA expression correlates with the central nervous system progenitor cell state in many, but not all, regions of the developing central nervous system. Dev. Brain Res. 84, 109-129.

DASH, P.K., MACH, S.A., and MO, A.N. (2001). Enhanced neurogenesis in the rodent hippocampus following traumatic brain injury. J. Neurosci. Res. 63, 313-319.

DOETSCH, F., CAILLE, I., LIM, D.A., et al. (1999). Subventricular zone astrocytes are neural stem cells in the adult mammalian brain. Cell 97, 703-716.

DOYLE, K.L., KHAN, M., and CUNNINGHAM, A.M. (2001). Expression of the intermediate filament protein nestin by sustentacular cells in mature olfactory neuroepitherium. $\underline{\mathrm{J}}$. Comp. Neurol. 437, 186-195.

DUGGAL, N., CHMIDT-KASTNER, R., and HAKIM, A.M. (1997). Nestin expression in reactive astrocytes following focal cerebral ischemia in rats. Brain Res. 768, 1-9.

FRANKLIN, K.B.J., and PAXINOS, G. (1997). The Mouse Brain in Stereotaxic Coordinates. Academic Press: San Diego.

GALVIN, K.A., and OORSCHOT, D.E. (2003) Continuous low-dose treatment with brain-derived neurotrophic factor or neurotrophin-3 protects striatal medium spiny neurons from mild neonatal hypoxia/ischemia: a stereological study. roscience 118, 1023-1032.

GRASL-KRAUPP, B., RUTTKAY-NEDECKY, B., KOUDELKA, H., BUKKOWSKA, K., BURSCH, W., and SCHULTE-HERMANN, R. (1995). In situ detection of fragmented DNA (TUNEL assay) fails to discriminate among apoptosis, necrosis, and autolytic cell death: a cautionary note. Hepatology 21, 1465-1468.

HOCKFIELD, S., and McKAY, R.D. (1985). Identification of major cell classes in the developing mammalian nervous system. J. Neurosci. 5, 3310-3328.

HOLMIN, S., ALMQVIST, P., LENDAHL, U., and MATHIESEN, T. (1997). Adult nestin-expressing subependymal cells differentiate to astrocytes in response to brain injury. Eur. J. Neurosci. 9, 65-75.

KAYA, S.S., MAHMOOD, A., LI, Y., YAVUZ, E., and CHOPP, M. (1999). Expression of nestin after traumatic brain injury in rat brain. Brain Res. 840, 153-157.

KURODA, T., NAKAMURA, H., ITOH, K., et al. (2002). Nestin immunoreactivity in local neurons of the adult rat striatum after remote cortical injury. J. Chem. Neuroant. 24, 137-146.

LI, Y., and CHOPP, M. (1999). Temporal profile of nestin expression after focal cerebral ischemia in adult rat. Brain Res. 838, $1-10$. 
MALHOTRA, S.K., SHNITKA, T.K., and ELBRINK, J. (1990). Reactive astrocytes-a review. Cytobios. 61, 133-160.

MASON, H.A., ITO, S., and CORFAS, G. (2001). Extracellular signals that regulate the tangential migration of olfactory bulb neuronal precursors: inducers, inhibitors, and repellents. J. Comp. Neurol. 405, 508-528.

MISSON, J.P., EDWARDS, M.A., YAMAMOTO, M., and CAVINESS, V.S., JR. (1998). Mitotic cycling of radial glia cells of the fetal murine cerebral wall: a combined autoradiographic and immunohistochemical study. Brain Res. 466, 183-190.

MISSON, J.P., TAKAHASHI, T., and CAVINESS, V.S. (1991). Ontogeny of radial and other astroglial cells in murine cerebral cortex. Glia 4, 138-148.

MIYAMOTO, O., SUMITANI, K., NAKAMURA, T., et al. (2000). Clostridum perfringens epsilon toxin causes excessive release of glutamate in the mouse hippocampus. FEMS Microbiol. Lett. 189, 109-113.

MOMMA, S., JOHANSSON, C.B., and FRISEN, J. (2000). Get to know your stem cells. Curr. Opin. Neurobiol. 10, 45-49.

NAKAMURA, T., MIYAMOTO, O., KAWAI, N., et al. (1999a). Therapeutic window of hypothermia after cold-induced injury in mice, in: International Conference on Recent Advances in Neurotraumatology. W. Chiu (ed), Monduzzi Editore: Italy, pps. 187-191.

NAKAMURA, T., MIYAMOTO, O., YAMAGAMI, S., et al. (1999b). The chronic cell death with DNA fragmentation after post-ischemic hypothermia in the gerbil hippocampus. Acta Neurochir. Wein. 141, 407-413.

NOCTOR, S.C., FLINT, A.C., WEISSMAN, T.A., DAMMERMAN, R.S., and KRIEGSTEIN, A.R. (2001). Neuron derived from radial glial cells establish radial units in neocortex. Nature 409, 714-720.

PARNAVELAS, J.G., and NADARAJAH, B. (2001). Radial glial cells. Are they really glia? Neuron 31, 881-884.

PARENT, J.M., VEXLER, Z.S., GONG, C., DERUGIN, N., and FERRIERO, D.M. (2002). Rat forebrain neurogenesis and striatal neuron replacement after focal stroke. Ann. Neurol. 52, 802-813.

PERRY, G., ZHU, X., and SMITH, M.A. (2001). Do neurons have a choice in death? Am. J. Pathol. 158, 1-2.

PRADA, F.A., DORADO, M.E., QUESADA, A., PRADA, C., SCHWARZ, U., and DE LA ROSSA, E.J. (1995). Early expression of a novel radial glia antigen in the chick embryo. Glia 15, 389-400.

RAKIC, P. (1972). Model of cell migration to the superficial layers of fatal monkey neocortex. J. Comp. Neurol. 145, 61-83.
RIESS, P., ZHANG, C., SAATMAN, K.E., et al. (2002). Transplanted neural stem cells survive, differentiate, and improve neurological motor function after experimental traumatic brain injury. Neurosurgery 51, 1043-1054.

SAHUQUILlO, J., POCA, M.A., GARNACHO, A., et al. (1993). Early ischemia after severe head injury. Preliminary results in patients with diffuse brain injuries. Acta Neurochir. Wein 122, 204-214.

SHIBUYA, S., MIYAMOTO, O., AUER, R., ITANO, T., MORI, S., and NORIMATSU, H. (2002). Embryonic intermediate filament, nestin, expression following traumatic spinal cord injury in adult rats. Neuroscience 114, 905-916.

SHIBUYA, S., MIYAMOTO, O., ITANO, T., MORI, S., and NORIMATSU, H. (2003). Temporal progressive antigen expression in radial glia after contusive spinal cord injury in adult rats. Glia 42, 172-183.

SUZUKI, M., and CHOI, B.H. (1991). Repair and reconstruction of the cortical plate following closed cryogenic injury to the neonatal rat cerebrum. Acta Neuropathol. 82, 93-101.

TAKAMIYA, Y., KOHSAKA, S., TOY, S., OTANI, M., and TSUKADA, Y. (1998). Immunohistochemical studies on the proliferation of reactive astrocytes and the expression of cytoskeletal proteins following brain injury in rats. Dev. Brain Res. 38, 201-210.

WEI, L.C., SHI, M., CHEN, L.W., CAO, R., ZHANG, P., and CHAN, Y.S. (2002). Nestin-containing cells express glial fibrillary acidic protein in the proliferative regions of central nervous system of postnatal developing and adult mice. Dev. Brain Res. 139, 9-17.

XU, R.X., NAKAMURA, T., NAGAO, S., et al. (1998). Specific inhibition of apoptosis after cold-induced brain injury by moderate postinjury hypothermia. Neurosurgery $\mathbf{4 3}$, 107-115.

YANG, H.-Y., LIESKA, N., KRIHO, V., WU, C.-M., and PAPPAS, G.D. (1997). A subpopulation of reactive astrocytes at the immediate site of cerebral cortical injury. Exp. Neurol. 146, 199-205.

Address reprint requests to: Takehiro Nakamura, M.D., Ph.D. Department of Neurological Surgery Kagawa University Faculty of Medicine 1750-1 Ikenobe, Miki-cho Kagawa 761-0793, Japan E-mail: neuron@kms.ac.jp 
This article has been cited by:

1. M.J. Pérez-Álvarez, C. Isiegas, C. Santano, J.J. Salazar, A.I. Ramírez, A. Triviño, J.M. Ramírez, J.P. Albar, E.J. de la Rosa, C. Prada. 2008. Vimentin isoform expression in the human retina characterized with the monoclonal antibody 3CB2. Journal of Neuroscience Research 86:8, 1871-1883. [CrossRef]

2. Tatsuki Itoh, Takao Satou, Shozo Nishida, Shigeo Hashimoto, Hiroyuki Ito. 2007. Immature and mature neurons coexist among glial scars after rat traumatic brain injury. Neurological Research 29:7, 734-742. [CrossRef]

3. Solène Sergent-Tanguy, Delphine C. Michel, Isabelle Neveu, Philippe Naveilhan. 2006. Long-lasting coexpression of nestin and glial fibrillary acidic protein in primary cultures of astroglial cells with a major participation of nestin+/GFAP- cells in cell proliferation. Journal of Neuroscience Research 83:8, 1515-1524. [CrossRef] 